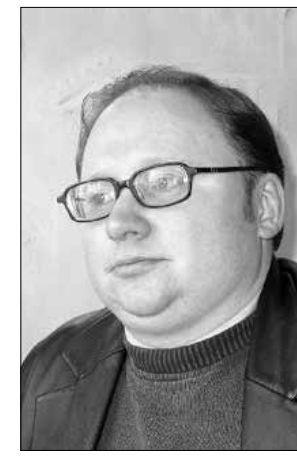

Vilniaus Gedimino technikos universitetas, Lietuva

Vilnius Gediminas Technical University, Lithuania

\title{
SCHOLASTINĖ LOGIKA LIETUVOJE: PRADŽIOS KLAUSIMAS IR METODAS
}

\author{
Scholastic Logic in Lithuania: \\ The Question of Beginning and Applied Method
}

\begin{abstract}
SUMMARY
The object of this article is scholastic logic in Lithuania. The author of the article concentrates on its historical beginning. It also describes the studied problems and teaching method applied in this logic. The article concludes that the beginning of scholastic logic in Lithuania should be dated back to 1507 . In that year Vilnius' Dominican monastery founded a school, in which a course of scholastic logic was delivered. Meanwhile, the philosophical and logical education of the laity in Lithuania was initiated by Jesuit Order, to which we should also be grateful for the development of scholastic logic. The article also concludes that scholastic Logic in Lithuania was an inseparable part of European scholasticism. In all scholastic Logic dealt basically with the same problems as well as applied the same method. The main features of the mentioned method are: authoritarianism, indifference to the facts of reality and excessive attention to details. On the other hand, this method is characterized by probabilism as well as by five-step argument technique that resulted in the scientific fairness of the researcher.
\end{abstract}

\section{SANTRAUKA}

Šiame straipsnyje analizuojama scholastinè logika Lietuvoje. Straipsnio autorius koncentruojasi ties jos istorine pradžia ir taikytu tyrimo bei dėstymo metodu. Prieinama prie išvados, kad scholastinès logikos pradžia Lietuvoje kol kas laikytini 1507 m. Tais metais prie Vilniaus dominikonų vienuolyno įsteigta partikuliarinė mokykla, kurioje pradėtas skaityti logikos kursas. Tuo tarpu filosofinį ir loginį pasauliečių lavinimą Lietuvoje pradèjo jèzuitų ordinas, kuriam privalome būti dèkingi ir už scholastinès logikos Lietuvoje išplètojimą. Straipsnyje taip pat teigiama, kad scholastinè logika Lietuvoje buvo neatskiriama europinės scholastikos dalis. Pastaroji visose savosios geografijos vietose iš esmès tyrè tas pačias problemas ir taike் 
tą pati metodą. Pagrindinès šio metodo savybès - autoritarizmas, dėmesio tikrovès faktams trūkumas ir perdètas dėmesys smulkmenoms. Kita vertus, jam būdingas ir probabilizmas bei penkių žingsnių įrodinėjimo technika, lèmusi mokslinį tyrinètojo sąžiningumą.

\section{IVADAS}

Logikos mokslo Lietuvoje atsiradimą turètume sieti su vidurinio mokslo pradžia Lietuvos Didžiojoje Kunigaikštystëje. Tuometinis vidurinis mokslas susidèjo iš dvieju pakopų. Žemesniąją pakopą - vadinamąji triviumą (trivium) - sudarè gramatika, retorika ir pirmoji scholastinès logikos dalis - dialektika. O aukštesniajai pakopai, arba kvadriviumui (quadrivium), priklause aritmetika, geometrija, astronomija ir muzika. Jei mokykloje buvo mokoma visų minètų laisvųju mokslų, arba menu (septem artes liberales), tokiai mokymo įstaigai buvo pripažǐstamas aukštesniosios mokyklos statusas. Tad septyniu laisvujjų mokslų arba bent jau triviumo dalykų dèstymo pradžią turime laikyti ir logikos mokslo Lietuvoje pradžia.

\section{LOGIKOS MOKSLO LIETUVOJE PRADŽIA}

Romano Plečkaičio teigimu, „mokslai Lietuvoje atsirado išsivysčiusio feodalizmo laikais, kai buvo pradèta steigti bajoru vaikams mokyklas, kurios tais laikais buvo dvasininku išlaikomos ir kontroliuojamos: jas steigè įvairūs vienuoliu ordinai, vienuoliai jose dèstė, pasauliečiu dèstytojų buvo mažai. Pirmoji tokia mokykla Lietuvoje issteigta 1387 m. prie Vilniaus katedros (Vilniaus kapitulos aktuose minima 1397). XV a. taip pat veikè Traku, Varniu, Kauno parapinės mokyklos, Vilniaus pranciškonų vienuolyno mokykla. <...> Didiku dvaruose buvo ir aukštesniojo lygio mokyklų; jų buvo ir turtingų miestiečių namuose. Samdyti mokytojai - dažniausiai baigusieji mokslus užsieniuose ir ten igiję bakalauro laipsnį, čia dèstė bajorų, pirklių vaikams mokslų pradmenis“ (Plečkaitis 1990: 122-123). To paties Lietuvos filosofijos istorijos tyrinètojo tvirtinimu, „manytina, jog didikų rūmuose ir turtingų miestiečių namuose veikusiose mokyklose mokè bent jau triviumo dalyku“" (123). Maža to, „panaši padètis turëjo būti ir Vilniaus katedros mokykloje“ (ten pat). Mat „viduramžiais katedrų mokyklų lygis visada buvo aukštesnis už parapinių mokyklų" (Plečkaitis 2004: 46). Taip pat, remiantis tuometinès Lenkijos katedru mokyklu mokymo programomis, galima spèti, kad ir Vilniaus katedros mokykloje XV a. galèjo būti dèstomi bent jau triviumo dalykai, o tarp ju - ir dialektika (46-47). Tad yra pagrindo manyti, kad jau XV a. kai kuriose Lietuvos mokyklose buvo dèstomas dialektikos kursas, kuris „čia buvo siauresnis negu universitetuose - logiką aiškindavo tiek, kiek ji buvo reikalinga retorikai“" (Plečkaitis 1990: 123). Vis dèlto „numatymas, kad Lietuvoje jau XV a. mokyklose buvo dèstoma logika, tebèra hipotezè, nes dokumentu, kurie tiesiogiai nurodytu tuometinèse mokyklose destytus dalykus, neturime“ (ten pat). 
Tad logikos mokslo Lietuvoje XV a. atsiradimas ligi šiol tebèra nei patvirtinta, nei paneigta hipotezè. Kita vertus, jau dabar tiksliai žinoma, kad logikos pradžia Lietuvoje datuojama bent jau 1507 m. Mat šiais metais galime fiksuoti scholastinès logikos dèstymą LDK. Tad būtent šią datą kol kas privalome tapatinti su aukštojo mokslo bei profesionalios filosofijos Lietuvoje pradžia. Būtent 1507 m. prie Vilniaus dominikonų vienuolyno buvo įkurta aukštesnio tipo mokykla (schola particularis), kurioje buvo dèstomi ir aukštojo mokslo - filosofijos ir teologijos - kursai ${ }^{1}$. Ši mokykla buvo apygardine, ji priimdavo kandidatus i dominikonų ordiną ir iš kitų LDK vienuolynų. Plečkaičio teigimu, „apie filosofijos studijas partikuliarinèje Vilniaus mokykloje daug ką tenka numanyti, nes joje skaitytų filosofijos paskaitų užrašų ar sukurtų traktatų iki šiol nerasta" (Plečkaitis 2004: 53). Vis dèlto remdamiesi scholastinès filosofijos dèstymo tuometinèje Europoje patirtimi, galime tvirtinti, jog pirmoji dominikonu mokykloje skaityto filosofijos kurso dalis privalèjo būti scholastinè logika, apimanti taisyklingo samprotavimo dèsnių mokančią dialektiką ir vadinamąją didžiąą logiką. Pastaroji buvo ne kas kita, kaip pažinimo teorija, tyrusi universalijų, Porfirijo predikabiliu, Aristotelio kategorijų etc. vaidmeni protinio pažinimo procese. Taip tvirtinti mums leidžia tas faktas, jog to meto universitetuose ir kolegijose skaitomas scholastinès filosofijos paskaitas sudarè logikos, fizikos, metafizikos ir etikos kursai, o per logikos paskaitas buvo déstoma dialektika ir didžioji logika. Taip pat galime teigti, kad Vilniaus dominikonų mokykloje dèstyta tomistine scholastinès filosofijos ir logikos versija (55), nes dominikonų ordinas aukščiausiu filosofijos autoritetu laikè būtent šv. Tomą Akvinietị, kuris jau nuo $1278 \mathrm{~m}$. buvo dominikonų ordino daktaras.

Tad logika, kaip ir kitos profesionalios scholastinès filosofijos disciplinos, buvo Lietuvoje jau XVI a. pradžioje; turima medžiaga leidžia tvirtinti, kad nuo 1507 m. ji buvo dèstoma Vilniaus dominikonų mokykloje. Ar ir kitų vienuoliu ordinu mokyklose tuo metu ar netgi anksčiau buvo skaitomas scholastinès filosofijos kursas, tebėra neišaiškinta. Kita vertus, tebėra atviras ir klausimas, ar tarp Vilniaus dominikonų mokyklos moksleivių buvo pasauliečių. Vis dèlto labiausiai tikètina, kad studijos Vilniaus dominikonų mokykloje buvo skirtos vien tik būsimiesiems šio ordino nariams. Mat filosofijos ir teologijos studijos buvo būtina isstojimo ị ordiną sąlyga. Tad filosofijos dèstymas Vilniaus dominikonu mokykloje turèjo būti orientuotas ì būsimų dvasiškių luomą.

Taigi pasauliečių filosofinio lavinimo Lietuvoje atsiradimas nèra sietinas su dominikonų ordino LDK veikla. Kaip pažymi Plečkaitis, ,iki jẻzuitų atvykimo filosofijos dèstymas Lietuvos vienuolynų mokyklose buvo siauro, uždaro pobūdžio, skirtas vien tik dvasininkų reikalams" (Plečkaitis 1990: 124-125). Tad pasauliečių filosofinio, o tuo pačiu ir loginio, švietimo Lietuvoje pradžią turètume sieti su jẻzuitų atvykimu i̇ Lietuvą 1569 m. bei jau po metu ikurta Vilniaus 
jèzuitų kolegija, $1579 \mathrm{~m}$. perorganizuota i Vilniaus universitetą kuri pradžioje sudare filosofijos ir teologijos fakultetai. $1571 \mathrm{~m}$. šioje kolegijoje įsteigtas logikos disciplina prasidedantis trijų metų filosofijos kursas, kurio klausytojai buvo tiek jëzuitų ordino nariai, tiek pasauliečiai. $\mathrm{O}$ Vilniaus universiteto filosofijos fakultete jau pirmaisiais universiteto gyvavimo metais studentai pasauliečiai skaičiumi nenusileisdavo dvasiškiams.

Su jëzuitu ordino veikla LDK turime sieti ne tik loginio pasauliečių lavinimo Lietuvoje pradžią. Šiam ordinui privalome būti dèkingi ir už scholastinès logikos Lietuvoje išplètojimą. Tiesa, logikos paskaitas Vilniaus dominikonu vienuolyno mokykloje reikia laikyti logikos mokslo Lietuvoje pradžia. Tačiau vèliau dominikonu pradėtą darbą pratęsè jėzuitai. Šio ordino atstovai apie du šimtus metu Vil- niaus jėzuitu kolegijoje ir Vilniaus universitete dèstė aukšto lygio scholastinę logika, o vienas iškiliausių universiteto dèstytoju - M. Smigleckis - savuoju „Logikos" veikalu pelnè platu tarptautini pripažinimą. Tiesa, scholastinès filosofijos Lietuvoje laikotarpiu logika, kaip filosofijos kurso dalis, buvo dėstoma ir kai kuriose kitu vienuolių ordinu (pranciškonu, bernardinu, karmelitu, dominikonu, trinitoriu, pijoru etc.) mokyklose. Be to, kai kuriose iš minètų mokyklu skaitytos logikos paskaitos savo lygiu nenusileido universitete dèstytam logikos kursui. Ir vis dèlto „Vilniaus akademija buvo Lietuvos jaunuomenès tuometinis švietimo centras" (Plečkaitis 1975: 38). Tad būtent Vilniaus jėzuitu akademijos dèstytoju indèli i scholastinès logikos Lietuvoje plètojimą privalome laikyti ženkliausiu ir įtakingiausiu.

\section{SCHOLASTINIS TYRIMO METODAS}

Scholastinè logika, kaip ir visa scholastine filosofija Lietuvoje, yra neatskiriama europinės scholastikos dalis. Pastarają privalome laikyti tarptautiniu kultūriniu fenomenu, kurio formos įvairiose Europos šalyse iš esmès nelabai kuo skyrèsi viena nuo kitos. Mat scholastine filosofija visur tyrè tas pačias problemas ir taikè tą pati metodą. Todèl ir scholastinès filosofijos Lietuvoje negalime vadinti Lietuvos scholastika - nèra jokių esminių bruožu, kuriais scholastinè filosofija Lietuvoje skirtųsi nuo scholastikos kitose Europos valstybėse. Tad kaip pažymi Plečkaitis, „scholastai Lietuvoje nesukūrẻ originalios mokyklos" (42).
Akivaizdu, kad šis pastebejjimas tinka visoms scholastikos Lietuvoje disciplinoms: logikai, gamtos filosofijai, metafizikai ir etikai. Tad nenuostabu, jog „palyginę P. Lauruso $1641 \mathrm{~m}$. Neapolyje dèstytą logikos kursą su Lietuvos mokyklų logikos paskaitomis, esminių skirtingumu neatrasime: nagrinejamos tos pačios problemos, taikomas tas pats metodas" (43).

Ši scholastini tyrimo ir dėstymo metodą galime apibrèžti kaip su teologija suderintų iš anksto žinomu tezių irodinèjimą scholastikos autoritetu (Aristotelio, Porfirijo, Aurelijaus Augustino, Avicenos, Boecijaus, Tomo Akviniečio, Džo- 
no Dunso Škoto, Viljamo Okamo, Durando, Petro Fonsekos, Francisko Suareso, Gabrielio Vaskeso ir kt.) argumentais. Tad esminiai šio metodo bruožai yra autoritarizmas bei dèmesio tikrovès faktams trūkumas. Tai sąlygoja, jos šis metodas iš esmès nesuderinamas su šiuolaikine mokslinio tyrimo samprata. Pastarosios požiūriu, i moksliškumą pretenduojanti tezè turi būti išvesta iš tikrovès tyrimo ar su juo siejama. Tuo tarpu scholastus nelabai domino tikrovès analizè - pastarająą dauguma jų laikè dalyku, priklausančiu ypatingo dèmesio nevertai empirikos sričiai. Tad ir tezès scholastinëje filosofijoje buvo priimamos kaip iš anksto duotos, o ju teisingumo patvirtinimui reikejo surasti šioms tezèms pritariančiu scholastikos autoritetų. Pastarụjų sąrašas paprastai priklausydavo nuo vienuolių ordino, kurio narys buvo tezes ginantis mokslininkas. Tiesa, visuotinis ir aukščiausias scholastikos autoritetas buvo Aristotelis - scholastinę filosofiją didžiąja dalimi galime laikyti šio filosofo veikalų komentarais. Tačiau dèl Stagiriečio komentatoriu svarbos bei ju pažiūrų teisingumo įvairūs ordinai nesilaikè vieningos nuomonès. Štai oficiali filosofinè dominikonu ordino doktrina buvo tomistinis aristotelizmas, pranciškonai teisingesne laike škotistinę Aristotelio interpretacija, jėzuitai dažniausiai pirmenybę teikè Suareso sukurtam aristotelizmo variantui ir t. t. Tad kokiu nors konkrečiu klausimu scholastas laikèsi iš anksto žinomos pozicijos, kurią išpažino jo ordino aprobuoti autoriai, jų autoritetas ordino akyse buvo svaresnis nei minètai pozicijai prieštaravusių antikinès bei scholastinès filosofijos atstovų.
Ir vis dèlto šiame metode galime ižvelgti elementa, suteikusi scholastiniam tyrinètojui tam tikrą pasirinkimo laisvę. Šiam elementui prigijo probabilizmo terminas (probabilis - lot. tikètinas, galimas). Probabilizmas scholastinejje filosofijoje reiškè, kad ginčytinais klausimais tyrinètojas neprivalëjo užimti kokią nors konkrečią poziciją ${ }^{2}$. Tokiu atveju visi galimi problemos sprendimo būdai buvo laikomi tikètinais. O konkrečiu sprendimo būdų tikètinumo laipsnis priklausè nuo jiems pritariančių scholastikos autoritetu skaičiaus ir svorio. Kitaip sakant, atsakymas i abejotiną klausimą buvo laikomas tuo labiau tikètinu, kuo didesnis scholastikos autoritetų skaičius gyne ši atsakymą ir kuo didesnès prabos buvo minètieji autoritetai. Tad probabilizmas nereikalavo, jog ginčytinu atveju būtų kategoriškai ginama kuri nors pozicija; tereikèjo ìvardyti esamas nuomones bei nurodyti ju tikètinumo laipsnį. Ši laipsni galëjo nustatyti pats tyrinètojas priklausomai nuo to, koki svariu scholastikos autoritetų skaičiu jis sugebėdavo atrasti gindamas kiekvieną nuomonę.

Tad probabilizmas paliko scholastiniam tyrinètojui tam tikrą pasirinkimo laisvę. Tačiau tai jokiu būdu nereiškia, kad pats probabilizmo fenomenas peržengè scholastinio autoritarizmo rèmus - ši fenomeną veikiau turètume laikyti savita minèto autoritarizmo apraiška. Mat būdamas akivaizdaus antiinovacinio pobūdžio, šis fenomenas įteisino tik minimalu tyrinètojo savarankiškumą. Kitaip sakant, probabilizmas neskatino nauju problemu bei galimu ju sprendimo būdu paieškos; jis tik i̇galino siaurą pasirinkimo laisvę rinktis iš tra- 
dicinių scholastinių problemų jau egzistuojančių sprendimo būdų.

Kita vertus, scholastiniame tyrimo metode galima izžvelgti ir dar vieną charakteringą bruožą. Tai tyrimo paskendimas daugybëje smulkmenų. Tiesa, pačios scholastikos požiūriu, ši savybė pretendavo i̇ mokslini griežtumą - spręsdami vieną ar kitą filosofinę problema, scholastai ręsdavo milžinišką gausių disputacijų, klausimų, abejojimų, skirs- tymų, tezių, šias tezes palaikančių argumentu, jas paneigiančių kontrargumentų etc. pastatą. Tačiau, kaip nurodo Plečkaitis, "scholastinis griežtumas tèra tariamas, išorinis griežtumas, jis galiausiai virsta gremėzdiška scholastikos veikalų ir paskaitų kursų sąranga. Kitaip sakant, „,tai paskendimas smulkiuose dalykuose, ginčai ir svarstymai mažareikšmiais, dargi akivaizdžiais klausimais, apeinant esminius dalykus“ (ten pat).

\section{SCHOLASTINIO ĮRODINĖIMO TECHNIKA}

Aptarę esminius scholastinio tyrimo metodo bruožus, pereikime prie jam būdingos tezių įrodinèjimo technikos. Šioji apėmè penkis žingsnius. Pirmasis jų vadinosi "Queritur an" (lot. - klausiama, ar iš tikrujuc yra būtent taip) ir buvo ne kas kita, kaip kokio nors scholastinès filosofijos aktualaus klausimo iškèlimas. Šis klausimo iškèlimas nebuvo nežinančiojo bandymas atrasti tiesą - klausime paprastai jau slypėdavo numanomas atsakymas (tezè). Pavyzdžiui, kai iškiliausias scholastinès logikos Lietuvoje autorius Smigleckis savo logikos paskaitose klausia, ar universalijos, arba bendrybès, yra duotos pačioje daiktų prigimtyje, jau iš karto galime būti tikri, kad atsakymas i minètą klausimą bus teigiamas (Smiglecius: 28). Antroji įrodinèjimo technikos dalis, arba vadinamasis „Videtur, quod non" (lot. - atrodo, kad iš tikrujuc yra ne taip) - tai numanomo atsakymo (tezès) priešininku argumentacijos pateikimas. Trečiajị irodinèjimo technikos žingsni "Sed contra" (lot. - tačiau iš tikrųju yra būtent taip) privalu laikyti numanomos tezès pagrindimu argumentais tų scholastikos autori- tetu, kurie, tezę iškèlusio tyrinètojo požiūriu, yra svariausi. O ketvirtasis žingsnis, arba "Dico", - tai klausime numanytosios tezès prièmimas. Šioje dalyje tyrinètojas galiausiai išreiškia savają pozicija, patvirtindamas aukščiau minètos tezès teisinguma, jo požiūriu, nenuginčijamų autoritetų argumentais. Galiausiai, paskutini scholastinio įrodinėjimo technikos žingsni "Respondeo" (lot. - atsakau) galima ivvardyti kaip tyrinėtojo priimtos pozicijos priešininkų ",sutriuškinimą", remiantis aukščiau minètų nenuginčijamų scholastikos metrų argumentacija.

Apibendrindami scholastini tyrimo metoda, pirmiausiai pabrěšime jam būdingą autoritarizma, dèmesio tikrovès faktams trūkumą ir perdètą dèmesi smulkmenoms. Dèl šių aspektų jis buvo pagrisstai kritikuojamas Renesanso ir Naujujų amžių filosofų ir gamtotyrinin$\mathrm{ku}$, kurie jame iž̌velgè ir praktinio naudingumo stoką. Mat Renesanso ir Naujujų amžių filosofija ir gamtotyra, daugiau ar mažiau laikydamasi F. Bacono iškelto orientyro „Žinojimas yra galia" (lot. - ipsa scientia protestas est), reikalavo, 
kad mokslinis tyrimas duotu praktiškai apčiuopiamų rezultatų. Tuo tarpu scholastinis metodas buvo abejingas empiriniam - eksperimentiniam tikrovès tyrimui, tuo pačiu pasmerkè scholastini mokslą praktiniam neveiksmingumui. Juk nesant tikrove paremto jos tyrimo, nèra ir adekvataus jos pažinimo, o stokojant pastarojo, neimanomas ir tikrovės ivaldymas bei užvaldymas.

Kita vertus, nedera absoliutinti neigiamų scholastinio tyrimo metodo aspek- tų. Juk jam būdingas probabilizmo elementas, iggalinęs tam tikrą scholastinio tyrimo laisvę. Maža to, šio metodo taikyta įrodinèjimo technika suponavo mokslinį tyrinètojo sąžiningumą. Scholastinès filosofijos atstovai, irodinèdami tezes savụjų autoritetu argumentais ir "triuškindami“" priešininku argumentaciją, tiksliai nurodydavo, kuriems autoriams priklauso šie argumentai ir iš kokių minètu autoriu veikalu ir netgi tu veikalu vietu tie argumentai yra cituojami.

\section{IŠVADOS}

Logikos mokslo Lietuvoje atsiradimas sietinas su scholastinès dialektikos ir logikos paskaitomis LDK mokyklose. Nèra žinoma, kada Lietuvoje perskaityti pirmieji dialektikos ir logikos kursai. Vis dèlto yra pagrindo spèti, kad LDK didiku rūmuose ir turtingu miestiečiu namuose veikusiose mokyklose, taip pat ir Vilniaus katedros mokykloje, buvo mokoma bent jau dialektikos. Kita vertus, tiksliai žinoma, kad logikos pradžia Lietuvoje kol kas galime laikyti $1507 \mathrm{~m}$. Tais metais prie Vilniaus dominikonu vienuolyno buvo įkurta aukštesnio tipo mokykla, kurioje buvo dėstoma filosofija ir teologija, o filosofijos desstymas prasidejo logikos paskaitomis. Tuo tarpu filosofini ir logini pasauliečių lavinimą LDK pradèjo jèzuitų ordinas, kuriam privalome

\section{Literatūra}

Madura Romanus Fabianus OP. 1972. Acta capitulorum provinciae Poloniae ordinis praedicatorum. Vol. 1 (1225-1600). Roma: Pontificium institutum studiorum ecclesiasticorum. būti dèkingi ir už scholastinès logikos Lietuvoje išplètojimą.

Scholastinè logika, kaip ir visa scholastinè filosofija Lietuvoje, buvo neatskiriama europinès scholastikos dalis. Pastaroji visur iš esmès tyre tas pačias problemas ir taikè tą pati metodą. Šis tyrimo ir dėstymo metodas - tai su teologija suderintų iš anksto žinomu teziu irrodinëjimas scholastikos autoritetų argumentais. Pagrindinès šio metodo savybès autoritarizmas, dèmesio tikrovès faktams trūkumas ir perdètas dèmesys smulkmenoms. Apskritai nedera absoliutinti neigiamų šio metodo aspektų. Jam taip pat būdingas probabilizmo elementas, igalinęs tam tikrą scholastinio tyrimo laisvę. Maža to, šio metodo taikyta penkiu žingsnių įrodinëjimo technika suponavo mokslinį tyrinètojo sąžiningumą.

Plečkaitis Romanas. 1975. Feodalizmo laikotarpio filosofija Lietuvoje. Filosofija Lietuvos mokyklose XVIXVIII $a$. I-II dalys. Vilnius: Mintis.

Plečkaitis Romanas. 2004. Lietuvos filosofijos istorija. 
T. I. Viduramžiai - renesansas - naujieji amžiai. Vilnius: Kultūros, filosofijos ir meno institutas.

Plečkaitis Romanas. 1990. Lietuvos filosofijos istorijos tyrimai ir jų perspektyva, R. Plečkaitis (ed.). Lietuvos filosofijos istorija. Paminklai ir tyrinejimai. I dalis: 115-136. Vilnius: Filosofijos, sociologijos ir teisès institutas.

Smiglecius Martinus. 1987. Commentaria in Organum Aristotelis (Vilnae, 1586-1587). Edidit L. No-

\section{Nuorodos}

1 Tokią aukštojo mokslo programą Vilniaus dominikonų mokykloje nurodo Lenkijos dominikonų provincijos kapitulos aktai. Štai $1507 \mathrm{~m}$. Sandomire susirinkusi kapitula nutarè: „Šiose bendruomenése steigiame partikuliarines studijas. <...> Lietuvos apygardoje: Vilniaus bendruomenëje" (Madura 1972: 166, cit. iš: Plečkaitis 2004: 48). Kapitulos sprendimu, pirmuoju Vilniaus dominikonų mokyklos filosofijos dèstytoju buvo paskirtas brolis Marianas Grozga. O 1524 m. Piotrkove vykusio kapitulos susirinkimo aktuose skaitome: „Patvirtiname Rusijos apygardos Lvovo bendruomeneje gramatikos ir logikos mokymąsi, Vilniaus bendruomenèje - wak. Warszawa: Akademia teologii jezuickiej, zeszyt 1 .

Swiętochowski Robert. 1975. Szkolnictwo teologiczne dominikanów, Rechowicz M. (ed.). Dzieje teologii katolickiej w Polsce. T. 2: Od Odrodzenia do Oświecenii. Cz. 2: Teologia neoscholastyczna i jej rozwój w akademiach i szkołach zakonnych: 211-285. Lublin: Wydawnictwo Towarzystwa Naukowego Katolickiego Uniwersytetu Lubelskiego.

teologijos ir filosofijos studijas" (Madura 1972: 264, cit. iš: Plečkaitis 2004: 51). Kaip nurodo Plečkaitis (1990: 124), „kaip partikuliarinė Vilniaus dominikonų mokykla kapitulos aktuose minima 1510, 1512, 1519 ir vėlesniais metais, žinomos keliolikos dèstytoju pavardès, pažymima, kad mokykloje dèstė bakalaurai". Šią dominikonu mokyklą bei joje dèstytus dalykus mini ir šio ordino istorijos Lenkijoje tyrinètojai (žr. Swiętochowski 1975).

2 Tokių abejotinų klausimų sąrašą paprastai nustatydavo vienuolių ordinų, kuriems priklause scholastinès filosofijos autoriai, vadovybès instrukcijos ir mokymo programos. 